Paideusis

\title{
Educating for Cultural Survival in Nunavut: Why Haven't We Learned from the Past?
}

\section{Barbara McMillan}

Volume 22, Number 2, 2015

Philosophical Perspectives on Education for Well-Being

URI: https://id.erudit.org/iderudit/1071456ar

DOI: https://doi.org/10.7202/1071456ar

See table of contents

Publisher(s)

Canadian Philosophy of Education Society

ISSN

0838-4517 (print)

1916-0348 (digital)

Explore this journal

Cite this article

McMillan, B. (2015). Educating for Cultural Survival in Nunavut: Why Haven’t We Learned from the Past? Paideusis, 22(2), 24-37.

https://doi.org/10.7202/1071456ar

\section{Article abstract}

This is a paper about the culture of the Inuit in the Nunavut Territory of the Canadian Arctic, and the role that education should take in preventing its slow dilution, demise, and loss. The measures to be taken are evident. Inuit philosophy (Inuit Qaujimajatuqangit) must be the framework, and Inuit must be in control, not only of policy and curricula, but also of the school system, the schools, and the classrooms. It can take decades for outsiders embedded in a different culture to communicate and see through an unfamiliar worldview. Inuit do not have the luxury of time to wait for this to happen. Non-Inuit need to understand what Inuit are saying, to appreciate what they aim to achieve, and then get out of the way. If this is not done, the Inuit culture will go the way of so many other Indigenous cultures that once flourished. It's inconceivable that we non-Inuit Canadians are willing not only to watch this happen but continue to be the cause.
This document is protected by copyright law. Use of the services of Erudit (including reproduction) is subject to its terms and conditions, which can be viewed online.

https://apropos.erudit.org/en/users/policy-on-use/ 


\title{
Educating for Cultural Survival in Nunavut: Why Haven't We Learned from the Past?
}

\author{
BARBARA MCMILLAN \\ Faculty of Education, University of Manitoba
}

\begin{abstract}
This is a paper about the culture of the Inuit in the Nunavut Territory of the Canadian Arctic, and the role that education should take in preventing its slow dilution, demise, and loss. The measures to be taken are evident. Inuit philosophy (Inuit Qaujimajatuqangit) must be the framework, and Inuit must be in control, not only of policy and curricula, but also of the school system, the schools, and the classrooms. It can take decades for outsiders embedded in a different culture to communicate and see through an unfamiliar worldview. Inuit do not have the luxury of time to wait for this to happen. Non-Inuit need to understand what Inuit are saying, to appreciate what they aim to achieve, and to collaborate in realizing these aspirations. If this is not done, the Inuit culture will go the way of so many other Indigenous cultures that once flourished. It's inconceivable that non-Inuit Canadians are willing not only to watch this bappen but continue to be a causal agent.
\end{abstract}

Two documents, written by Inuit for Inuit in Canada's north, have attempted to establish what is to be taught in Nunavut Territory schools. These documents are Inunqatigiit: The Curriculum from the Inuit Perspective (Government of Northwest Territories - GNWT, 1996) and Inuit Qanjimajatuqangit: Education Framework for Nunavut Curriculum (Nunavut Department of Education - NDE, 2007). Both focus on the education of the whole child, Inuktitut language preservation, and the promotion of Inuit values and beliefs. Values are explained as ways of being in family, community/society, and environment. They are considered "a guide to help one become a good person" (NDE, 2007, p. 33). Beliefs "ensure values are practiced, followed, honoured and passed on" (GNWT, 1996, p. 8). They are explications of good behavior and well-being. Each publication provides a compilation of values, and the Inuit elders who are the authors go to great lengths to describe these, as well as the foundations of their worldview. As one example, under the subheading Circle of Belonging, one reads "Family and kinship link a person's identity to a certain group of people. This group of people belongs to the land ... The concept of 'the land' included not just the earth itself, but all of nature: plants, animals, water, ice, wind and sky. Nature and Inuit are one" (GNWT, 1996, p. 31). For the non-Inuit teacher educated in southern Canada and teaching in Nunavut, what meaning might the statement "Nature and Inuit are one" have? Is it simply a matter of living on the land, gaining sustenance from the land, and being sustained by the land? Environmental stewardship? "Being humble and respectful of the rights of all things"? Is it possible for an individual who has grown up in a culture focused, as Rasmussen (2011) describes, on placelessness, waged labour, wealth-getting, consumerism, possessive individualism, environmental despoilment... (everything that Inuit and Inuit society have not traditionally been) to come to know the complexities of the Inuit-environment relationship so that these values associated with well-being can be presented in classrooms, discussed, practiced and honoured?

It is 2015, and the Inuit in the territory of Nunavut are in their sixteenth year of advocating for an education system in their homeland that incorporates all that John Amagoalik so prudently expressed: "We must teach our children their mother tongue ... what they are and where they come 
from ... the values that have guided our society over the thousands of years ... our philosophies which go back beyond the memory of man" (1977 as cited in Nunavut Department of Education, 2007 , p. 4). Unfortunately, the vast majority of teachers, school administrators, and Department of Education employees continue to be non-Inuit (Rasmussen, 2011), and Inuit languages and heritage continue to erode (Nunavut Tunngavik Incorporated - NTI, 2011). Not only do a majority of Inuit leave secondary school before graduation (National Committee on Inuit Education, 2011; Inuit Tapiriit Kanatami - ITK, 2014), but resettlement and this period of rapid social change, which Inunqatigiit and Inuit Qaujimajatuqangit attempt to ameliorate, have been characterized by "the disempowerment of Inuit and the breakdown of traditional gender and community roles in a way that has thrown an entire society out of balance" (NTI, 2013, p. 7). The result is numerous social problems including physical and mental health issues with few programs and services to improve health and well-being (NTI, 2013; Tagalik, 2009-2010a). It has been argued that the school system in Nunavut plays a role in Inuit society being "out of balance" (Berger \& Epp, 2006; Berger, 2009; Tagalik, 2009-2010a; Rasmussen, 2011; ITK, 2014a; NTI, 2011. One can't help but wonder if it is possible for a school system in Nunavut, staffed by a preponderance of non-Inuit, to educate for well-being when an understanding of well-being is tied to worldview and, thus, means something different for cultures as disparate as those in Canada's north and south.

This paper is an attempt to answer that question. I begin by reviewing the social determinants of health and well-being from Nunavut Inuit perspectives. I then explore the meanings associated with the Inuit Quajimajatuqangit (IQ) philosophy and describe how these beliefs, laws, principles, and values have provided a framework for education in Nunavut. This leads to a discussion of the difficulty of incorporating $I Q$ in instruction in Nunavut classrooms when it is necessary "to go beyond what we think we see and hear and ask what a person from a different culture and with a different sense of reality is truly trying to tell us" (Ross, 2006, p. 5). Using the experiences of others, I argue that the act of engaging in Inuit and Western systems of knowledge as a two-way transaction may be easy to write about in policy and curriculum documents but extremely difficult for non-Inuit teachers and Inuit teachers with limited cultural knowledge to enact with the understanding and cultural humility required. If Inuit culture as understood by elders is going to survive, education must be an enabler, and enabling in this situation requires a deep understanding of, and resolute commitment to, IQ.

\section{Social Determinants of Inuit Health}

The World Health Organization (WHO) has defined the social determinants of health as being "the conditions in which people are born, grow, live, work and age... [that] are shaped by the distribution of money, power and resources at global, national and local levels, which are themselves influenced by policy choices" (WHO, 2014). As such, health inequalities are considered a matter of social justice and were labeled as such in 2008 when the WHO-sponsored Commission on Social Determinants of Health claimed "social injustice is killing people on a grand scale" (p. iii).

Inuit Tapiriit Kanatami (ITK) represents the 59,500 Inuit living in the fifty-three Arctic communities located in Nunatsiavut (Labrador), Nunavik (Northern Quebec), Inuvialuit Region of the Northwest Territories, and Nunavut as well as those Inuit (27\% in 2011) who have settled in southern Canada (2014, p. 9). In September 2014, ITK published Social Determinants of Inuit Health in Canada. The writers of the report identify eleven social determinants of Inuit health that are responsible for health inequities. These are "quality of early childhood development, culture and language, livelihoods, income distribution, housing, personal safety and security, education, food security, availability of health services, mental wellness, and environment" (ITK, 2014, p. 11-37).

Of particular interest here are those determinants most closely linked to Inuit Quajimajatuqangit philosophy and the incorporation of this philosophy in pedagogy and school curriculum. These are environment, culture/language, and education. By environment, the ITK does 
not only refer to indoor home and work environments. The "challenging factors" associated with this determinant refer to the natural environments - the land (nuna), the sea (tariuq), and the sky (sila) surrounding the fifty-three Inuit communities (p. 36). These once pristine environments are responding to changes in climate and to the accumulation of persistent organic compounds in Arctic food webs. In doing so, they are having substantial impacts on over-land and over-water/ice travel, access to country foods, hunter safety, diet, food security, and economic, spiritual, and cultural traditions, particularly the complex relationship of Inuit to "the land".

Inuktitut, like other Indigenous languages, is an indispensable part of Inuit identity. Moreover, these ancient oral languages convey "a sense of responsibility, and a sense of spiritual relationship to the universe" (Leona Marokis as cited in Ross, 2014, p. 38). Tagalik, in fact, claims that "[c]onceptually, $I Q$ is less able to be expressed and transmitted in a written form" (2009-2010a, p. 6). Inuktitut loss, as a result, is equivalent to Inuit losing "their distinct sense of the world and their place within it" (Ross, 2014, p. 40). This understanding was affirmed by Mary Simon when speaking at the 2008 Arctic Indigenous Language Symposium in her capacity as president of Inuit Tapiriit Kanatami: "Our language is who and what we are and the health of our language lies at the core of our wellbeing" (Simon, 2008 as cited in NTI, 2011, p. 8).

According to 2006 census data, of the 50,485 Inuit in Canada, just over $64 \%$ or 32,200 reported Inuktitut as the language learned at home during childhood, and 50\%, approximately 25,500, reported Inuktitut as the language most often spoken at home (Statistics Canada, 2009). These census figures show a slow decline from the 1996 Statistics Canada data. Writers of the report, however, note that the census figures conceal regional differences between high Inukitiut language use in Nunavik and Nunavut and lower Inuktitut language use in Nunatsuavut, and the Inuvialuit region of the NWT as well as differences between the Inuit Nunaat population and the population of Inuit living in urban and rural areas outside Inuit Nunaat. The 2011 National Household Survey (Statistics Canada, 2013) reveals that the proportion of Inuit who converse in Inuktitut continues to decrease: $58.7 \%$ of Inuit reported Inuktitut as their mother tongue and $45.9 \%$ reported Inuktitut as the language spoken most often at home.

Nunavut Tunngavik Incorporated (2007) policy documents call for full bilingualism in Inuktitut and English languages and a kindergarten through grade 12 teaching force that is increasingly made up of Inuit teachers. A November 2013 report from Canada's Auditor General showed that the Nunavut government would not meet its goals for bilingual education for all students by the 2019-2020 school year (Canadian Broadcasting Corporation, 2013). To do so, all schools in the territory would need to be offering Inuktitut and English language instruction from kindergarten through grade 4. Five schools were involved in the Auditor General's report and only one of these was offering bilingual instruction in grade 4. When ITK published Social Determinants of Inuit Health in Canada in 2014, all Nunavut schools offered Inuktitut instruction from kindergarten to grade 3.

In conversations with Igloolik teachers and community members, it was evident that the time set aside for Inuktitut language instruction in upper elementary, junior high, and senior high schools was insufficient. Many referred to the erosion of the language, as simple noun-based English words were commonly being substituted for complex, multi-syllabic, verb-based Inuktitut words in oral conversations. This was a great concern in light of the inflow of the newest sources of English language in the home: satellite television and the internet.

It's clear from the ITK and NTI reports cited that Inuit don't deny their lack of wellness and well-being. In her review of the literature and work with elders across the territory of Nunavut, Tagalik attributes this condition to a break in the transmission of Innit Quajimajatuqangit caused by colonization. By colonization she specifically refers to the following:

(a) forced relocations into communities that tore Inuit away from "the way of life that has sustained them for generations" and placed them in political and socio-economic environments "for which they had no compass" (2009-2010a, p. 4); 
(b) "the establishment of a set of social systems and institutions ... such as schools, health centres, social service agencies, and correctional centres" that paid little if any attention to Inuit values, relationships, and ways of maintaining harmony (p. 4);

(c) "the dislocation of [Inuit] leadership" with its power-sharing in face-to-face interactions amongst equal and interdependent men and women and decision-making through consensus (p. 6);

(d) language loss and the concomitant "decrease in understandings of the concepts linked to words and the relevance of the word itself as it relates to the cultural experience" (Doras, 2006 as cited in Tagalik, 2009-2010a, p. 6); and

(e) cultural appropriation and cultural dilution of the Inuit view of the world (2009-2010a, p. 7).

The solution for healing from a colonial past proposed by Inuit elders is $I Q$, "the foundation of wellbeing," with its focus on cultural proficiency, cultural strengths, and interdependent relationships (Tagalik, 2009-2010a, p. 7). Tagalik (2009-2010b) begins to explain this in a report titled Inutsiaqpagutit - That Which Enables You to Have a Good Life. She writes:

...leading a good life focuses on personal and collective obedience to following the teachings that are foundational to Inuit worldview or Inuit Qaujimajatuqangit. Although each of these teachings is defined separately, they are followed holistically and are viewed as interconnected and inseparable. So, if you are experiencing difficulty in one area of your life, that likely will affect both you and those around you in other areas as well. For this reason, and 'in order to live untroubled,' adherence to the teachings is a priority. ... Ill health stems from a fundamental breakdown in the conditions that support health, either physical, sociocultural, economic or mental. In the case of post-colonial trauma, all of these conditions became broken for Inuit populations. (p. 5)

\section{Inuit Quajimajatuqangit Philosophy}

Inuit Quajimajatuqangit has been translated as "the wisdom gained from extensive experience that has been passed from generation to generation" (Nunavut Social Development Council, 2000), "the Inuit way of knowing" (Pauktuutit, Inuit Women of Canada, 2006, p. 6), "that which Inuit have always known to be true" (Tagalik, 2009-2010a, p. 1), "the ancient knowledge of the Inuit (Wezel, 2004, p. 241), "Inuit traditional knowledge" (Wihak, 2004, p. 30), and "the Inuit way of doing things, and includes past, present and future knowledge of Inuit society" (Bell, 2002, p. 3).

The term "Inuit Qaujimajatuqangit embraces all aspects of traditional Inuit culture, including values, world-view, language, social organization, knowledge, life skills, perceptions and expectations" (Nunavut Social Development Council, 1999 as cited in NDE, 2007, p. 20). It is considered "a philosophy and way of living and thinking" (Nunavut Ministry of Culture, Language, Elders and Youth, 2000 as cited in Tester \& Irniq, 2008, p. 51), "a political tool to give more space to Inuit perspectives" (Laugrand \& Oosten, 2009, p. 125), "a form of resistant practice that can seriously challenge characteristic assumptions of Western science" (Tester \& Irniq, 2008, p. 48), a description of "Inuit epistemology ... that is consistent with Inuit worldview" (Tagalik, 2009-2010a, p. 1), and "a living technology... a means of rationalizing thought and action, a means of organizing tasks and resources, a means of organizing family and society into coherent [seamless] wholes" (Arnanak, 2000, p. 1).

The IQ framework is based upon four laws or maligait identified by Inuit elders from across Nunavut. According to Tagalik (2009-2010a), "[a]ll cultural beliefs and values are associated with the 
implementation of these maligait," which ultimately contribute to "living a good life which is described as the purpose of being" (p. 1). These laws are "working for the common good," "respecting all living things," "maintaining harmony and balance," and "continually planning and preparing for the future" (p.1). The six guiding principles "form the basis of an interlocking conceptual philosophy for $I Q \ldots$ [and collectively] form a plan for the continuous application of $I Q$ in Inuit society" (p. 2). These core principles as presented by Arnakak, in italics (2000, p. 2), and elaborated upon by Laugrand and Oostenand (2009, pp. 125-126) are as follows:

1. Pijitsirniq - the concept of serving a purpose or the community, and providing to one's family and/or community an authoritative as opposed to authoritarian leadership role;

2. Aajiiqatigiingniq - the concept of consensus decision-making through conferences (implies a way to involve communities in their own development as learning organizations and seeks to improve consultation processes as well as monitoring and evaluation methods);

3. Pilimmaksarniq - the concept of skills and knowledge acquisition gained through observation and experience that lead to empowerment;

4. Piliriqatigiingniq - the concept of collaborative relationships or working together for a common purpose and the common good;

5. Avatimik Kamattiarniq - the concept of environmental stewardship); and

6. Qanuqtuurunnarniq - the concept of being resourceful to solve problems.

According to Arnakak, these six IQ principles "hint at an idealized Inuit psychology" (2000, p. 4) that is based upon respect, charity, trust, discipline and restraint. Harmony and balance are a consequence of each Inuk living in obedience to these principles, and it is balanced harmony that is believed to contribute significantly to the well-being of individuals, families and communities "by providing a purpose and direction in life" (Tagalik, 2009-2010a, p. 2). In contrast, "[b]eing in a state of imbalance will lead to ill health" (Tagalik, 2009-2010b, p. 5).

The six Inuktitut words with their English language descriptions only begin to reveal the meaning of these $I Q$ principles for Inuit and hint at their value in restoring what has been lost through colonization. As has been described, IQ unites the entire realm of Inuit experience from values and beliefs to skills; all of which came into being and evolved as a result of this experience in the world. As Tagalik asserts, "[i]t is the experience and resulting knowledge/wisdom that prepares us [Inuit] for success in the future and establishes the possible survival of Inuit" (2009-2010a, p. 2).

\section{IQ and Education in Nunavut}

Given that "IQ is the foundation upon which social/emotional, spiritual, cognitive and physical wellbeing is built" (Tagalik, 2009-2010a, p. 3), and the strong belief that the knowledge that sustained Inuit for centuries should be preserved and passed on to younger generations, the decision was made to infuse Nunavut school curricula, teaching material, and learning resources with $I Q$ philosophy that included the four laws and the six guiding principles (Government of Nunavut, 2013). The IQ: Education Framework for Nunavut Curriculum, however, was expanded to include two additional guiding principles. These are "Inuuqatigitsirniq or showing respect and a caring attitude for others" and "Tunnganarniq or being welcoming of others, being open in communications and inclusive in the ways of interacting" (NDE, 2007, p. 30), and with these eight guiding principles IQ: Education Framework for Nunavut Curriculum is "the source of nearly all policy, curriculum, and programming undertaken by the [Nunavut] Department of Education" (McGregor, 2012, p. 296). The goal "is to provide a 
learning environment where silaturniq (becoming wise) is fostered, and within which the strength of inummarik (a capable person) can develop" (NDE, 2007, p. 20).

To attain this goal, a five-stage learning continuum is identified that begins with the emergent learner in early years and progresses along a path with the following transition points: transitional learner in middle elementary, communicative learner in upper elementary, confident learner in late middle and junior years, and proficient learner in senior years (Nunavut Department of Education, 2007). Developed throughout the learning continuum are (a) the eight core $I Q$ principles with each transition point having end-of-stage competencies and (b) the four generic, cross-curricular strands that transcend school subjects. The strands are an attempt to move away from subjectspecific content knowledge and "to focus on the development of complex intellectual (metacognitive) skills and lead students to transformational ways of thinking and processing" (NDE, 2007, p. 47). As one example, the strand Nunavusiutit incorporates information on heritage, culture, history, geography, environmental science, civics, economics, current events, and world news. The learning focus is "Nunavut and its critical links to national, circumpolar and global issues" (NDE, 2007, p. 47). The remaining three strands, Iqqaqqaukkarngniq, Uqausiliriniq, and Aulajaaqtut, are focused on "ways in which we improve our world," "relationships," and "wellness, safety and one's place in society," respectively (NDE, 2007, p. 47). Iqqaqqaukkarngniq incorporates mathematics, technology and practical arts with analytical and critical thinking, solution-seeking, and innovation. Uqausiliriniq integrates communication, language development, creative and artistic expression with reflective and critical thinking. Aulajaaqtut merges physical, social, emotional, and cultural wellness with goal setting, volunteerism, and survival (NDE, 2007).

As laid out in the Nunavut Education Act (GN, 2008), it is the responsibility of the Minister of Education, the district education authority in each community, and the education staff of each school "to ensure that Inuit societal values and the principles and concepts of Inuit Qaujimajatuqangit are incorporated throughout, and fostered by, the public education system" (GN, 2013, p. 8). District education authorities are required to "ensure that the school program is founded on the principles and concepts of Inuit Qaujimajatuqangit and respect of Inuit cultural identity" (p. 8 ), and the Minister of Education is to establish school curricula that address Inuit societal values, cultural identity, and the principles and concepts of IQ (p. 8).

School staff, including teaching staff, is addressed in Part 11 of the Nunavut Education Act, Section 96, which requires that orientation and mentoring programs be developed by the Minister of Education in accordance with, and based upon, Inuit societal values and the principles and concepts of IQ. Teachers are to participate in these programs "during the first two years after they take up the duties of their positions to integrate them into the Nunavut school system." Under Section 98, teachers are required to teach students in a manner that is consistent with Inuit values and identity and $I Q$ principles, and it is the duty of the school principal, a committee of elders, and the district education authority to monitor and evaluate the carrying out of Section 98 by members of the school staff and to report this information to the Minister of Education. There is no indication of consequences from such an evaluation process, particularly the multilayered evaluation of non-Inuit and Inuit teachers who may or may not have more than a superficial understanding of $I Q$, Inuit identity, and Inuit worldview. Looking at the Inuit laws and guiding principles that are the foundation of formal education in Nunavut, one questions the meaning that the English translations of these Inuktitut concepts will have and currently do have for teachers, both Inuit who have experienced cultural erosion and language loss and non-Inuit.

\section{The Difficulty of Developing of "Two-Eyed Seeing"}

In a 2012 issue of Canadian Journal of Nursing Research, Martin presents a "two-eyed seeing" theoretical framework for research that brings together contributions from both Indigenous and Western ways of knowing. She acknowledges Mi'kmaw elders Albert and Murdena Marshall for developing and 
proposing the two-eyed seeing "lens" (p. 24). This "lens" is similar, if not identical, to the "two ways of knowing" (the merging of Inuit traditional knowledge and Western science) that was the focus of a workshop held in Winnipeg in 2002 and promoted during the Fourth International Polar Year (IPY) - Circumpolar Flaw Lead System Study based out of the University of Manitoba (Barber \& Barber, 2009).

In each case, two-eye seeing is being mindful of alternative ways of knowing. It is a "transcultural collaboration" (Hogue \& Bartlett, 2014, p. 26) in which diverse knowledge systems coexist; one informing the other, not for one perspective (or "eye") to subsume or dominate the other. The goal is to value difference, contradiction, and diverse perspectives that two-eye seeing make possible. Such an approach is thought to enable one to obtain a more complete picture and perhaps a new way of thinking or a higher level of understanding (Martin, 2012). The depth at which one individual can see through two cultural perspectives is not described. Yet, as will be shown, this information is extremely important when thinking about teachers, particularly Inuit and non-Inuit teachers with limited cultural knowledge, who are teaching Inuit students in Nunavut.

\section{Seeing the World with Aboriginal Eyes}

In Seeing the World with Aboriginal Eyes, author David Rice (2005) poses questions relevant to the present discussion. For example, "How can we learn what is unique and particular about Aboriginal peoples' understandings?" (p. 1). "Can an outsider who lives in an Aboriginal society become immersed enough in the culture to truly understand its worldview?" (p. 1). "Can a bi-cultural person function equally in both cultures, even if those cultures are at variance with each other?” (pp. 1-2). "Is it possible to the extent necessary to understand another culture?" (pp. 4-5). At the time of writing his book, Rice, of Mohawk and Finnish descent, had spent many years involved in traditional Aboriginal practices and had taught university courses in Native Studies. Even so, he admitted to being in the process of reconstructing his Mohawk identity based on lost traditions. He acknowledged that it would be many years before achieving his goal of "seeing the world with Aboriginal eyes" (2005, p. 2).

Marie Eshkibok-Trudeau (2000) writes about the intentional, although informal, culturebased education of her daughter, Binaaskikwe/Elizabeth, in a paper titled "Circular Vision: Through Native Eyes." This home-schooling and culturation, which began at birth and has continued throughout her daughter's life, includes vision quest teachings, fasting teachings, Native language scroll teachings, and sweatlodge teachings. In order for Binaaskikwe to apply the sacred Anishinaabe teachings and Odana way of living to her own life, Eshkibok-Trudeau contends that they needed be experienced through vision questing, which she identifies as $360^{\circ}$ or circular vision. Such knowledge could not be learned by listening to and reading about these events in school and church. As Eshkibok-Trudeau explains:

\footnotetext{
Although many myths and legends have been recorded, written down and studied, they have not been understood by those who function with linear vision [or with "white eyes"]. One of the reasons for this is the lack of understanding of the Native language used by the elders to tell these stories. These stories have been written down in English and they have lost their meaning [particularly their powerful spiritual constructs that form the basis of moral conduct]. (p. 14)
}

For similar reasons, David Rice advises using readings as reference points (2005, p. 1). He also refers to finding a mentor, cultural teacher, or elder to help with the "long, slow and laborious process" of coming to knowing (2005, p, 3), and claims that to fully see the world with Aboriginal eyes "means becoming immersed in a particular Aboriginal world view, being wholly integrated into a way of life, ceremonies, language and culture" (2005, p. 1).

The focus of both of these Aboriginal authors is language, ceremony, and a way of living that is spiritual and relational, and, for Eshkibok-Trudeau, the age at which the cultural education 
should begin. It is the thinking of scholars like Marie Battiste and James (Sa'ke'j) Youngblood Henderson (2000) that provides clarity for non-Aboriginals wishing to understand, not only know, cultural traditions, customs, knowledge systems, and how this knowledge is acquired and transmitted within a particular culture. In the chapter titled "What is Indigenous Language?" they state:

\begin{abstract}
Since languages house the lessons and knowledge that constitute the cognitive-spiritual process of groups of people in specific places, Indigenous peoples view their languages as forms of spiritual identity. Indigenous languages are thus sacred to Indigenous peoples. They provide the deep cognitive bonds that affect all aspects of Indigenous life. Through their shared language, Indigenous people create a shared belief of how the world works and what constitutes proper action. Sharing these common ideals creates the collective cognitive experience of Indigenous societies, which is understood as Indigenous knowledge. Without Indigenous languages, the lessons and the knowledge are lost. (2000, pp. 48-50)
\end{abstract}

It is for reasons such as those described by Battiste and Henderson that Laugrand and Oosten (2009) make reference to what they identify as the unsuccessful integration of $I Q$ in the Western school system of Nunavut. The danger they foresee is an appreciation of the "practical usefulness" of $I Q$ and an abandonment of the central moral laws and guiding principles owing to a perceived irrelevance in the twenty-first century by all but Inuit elders (p. 127). This is an example of what Tagalik refers to as cultural appropriation and cultural dilution in her discussion of the consequences of colonialization. In a similar vein, Chartrand (2012) raises concerns over the integration of "pan-Aboriginal" topics like "The Seven Teachings" or "The Aboriginal Seven Teachings" that overshadow the Anishinaabe origins of The Seven Teachings and "shape shift from school to school" creating "a mishmash of information that continues to misinform" (p. 146). If we recognize that translated words and reproduced images fail to well represent a specific people's songs, legends, stories, knowledge, and works of art, are we also to conclude, as Daes claims, that " $[t]$ he diverse elements of an Indigenous people's heritage can only be fully learned or understood by the means of the pedagogy [and language] traditionally employed by these peoples themselves, including apprenticeship, ceremonies and practice"? (1994 as cited in Battiste \& Henderson, 2000, p. 19)

\title{
Possible Solutions
}

The stories told and the research literature presented above suggest that two-eye seeing and walking naturally in two worlds (Eurocentric/Western and Aboriginal/Indigenous) is not only challenging, if achievable, but deeply troubling when learning is superficial and/or fragmentary and, therefore, erroneous. How then might one begin, if the aim is to sustain the Inuit culture and, thus, the restoration and continuance of personal and community well-being by means of $I Q$ ?

One possibility would be to follow the successful approaches of the Māori in Aotearoa/New Zealand with their Kōhanga reo Māori (Māori-language preschools) and Kura kaupapa Māori (Māorilanguage immersion schools). Such initiatives in Nunavut would be hindered by the same issues schools currently face: shortages of Inuktitut-language resources and teachers fluent in Inuktitut. A second possibility, suggested by elders I have interviewed in the Qikiqtaaluk Region of Nunavut, is to divide the school day, week, or year into two equivalent periods, and to teach Inuit ways of knowing and being in one of these periods and the standard school subjects in the other. Such an approach would allow for a focus on IQ and the cultivation of Hampton's (1993) "Twelve Standards of Education for Aboriginal Students" along with items from Jacobs' (2013) pedagogy and procedures checklist for employing "dialogic and Indigenous approaches to teaching and learning" (p. 79). These include, and are not limited to, spirituality, ceremony, service to community, respect for diversity, sense of place, culture, experiential learning including field experiences, the natural world as teacher, community involvement, the use of humor, storytelling, dream work, songs, music, and peer teaching. A third approach, promoted in science education, is Aikenhead and Michell's (2011) 
"bridging cultures." Rather than separating Indigenous ways of living in nature and Eurocentric science, they believe that both ways of describing, knowing, and explaining nature can coexist, improve science lessons, and enrich understanding. This approach draws upon of two ways of knowing and results in what Aikenhead and Jegede (1999) have called the collateral learning continuum. A science learner with an Indigenous worldview, for example, may store two conflicting ideas in long-term memory and switch between these ideas depending upon the context (for example, school science or on the land with an elder). This is referred to as parallel collateral learning. At the opposite end of the continuum, the science learner links the two conflicting ideas in a way that allows for a convergence of the science knowledge with Indigenous knowledge. This is referred to as secured collateral learning. For this convergence to occur, the science teacher must "create bridges between Indigenous knowledge and Eurocentirc knowledge" by examining, with students, how each culture explores and makes sense of nature (Battiste, 2000 as cited in Aikenhead \& Michell, 2011, p. 6).

This brings us back to how an Inuit or non-Inuit teacher comes to know and understand IQ in order to bridge these two cultural ways of knowing so as to educate for well-being. I want to suggest two methods that don't initially oblige a teacher to learn the Inuktitut language while living out her professional life in Nunavut. The first requires the development of teacher resources that highlight the Inuit worldview using the traditional legends and stories of the Inuit and the lessons they contain and supplementing these narratives with what Richard Atleo refers to as analytic commentary. I will use Atleo's writing as an illustration of such potential resources. The second involves bi-cultural teaching and, as frequently as possible, a collaboration between Inuit elders and/or knowledgeable community members and Inuit and non-Inuit teachers who are in the process coming to understand IQ and the importance of cross-cultural (bridging) instructional strategies. Wetzel's narrative of the polar bear will be used to illustrate how valuable such collaborations can be for learners.

\section{Atleo's Nuu-chah-nulth Origin Story: A Model Resource}

In his story "How the Son of Raven Captured the Day," Atleo (2004) helps readers to know that the physical and spiritual worlds are experientially one, that physical beings originated in the spiritual realm, that communication and travel between these two worlds were not unusual although protocols and rituals had to be followed, and that darkness preceded light in the physical world. Then, he helps readers to see the qualities in the story's characters that make a community possible (such as cooperation, kindness, helpfulness, hard work, patience, perseverance, endurance, and humility). Atleo describes "How the Son of Raven Captured the Day" as a story of love: "One of our own, with community involvement, brings home the light. Everyone has helped. It's a funny, beautiful story. It has a great ending." He's correct on all accounts, but for non-Aboriginals, it's a funny, beautiful story with a great ending because he has carefully taken readers through the story a second time and explained the meaning of each act in both worlds.

If legends were presented as Atleo presents the Nuu-chah-nulth origin story, Rice and Eshkibok-Trudeau, whose experiences were described above, might consider text, including the English translations of stories with an oral legacy, as having greater value. Atleo's retelling of the Son of Raven story and his thorough, unencumbered interpretation and analysis of the events through his Nuu-chah-nulth worldview is exactly what is needed to show how such stories "inform... as well as form" members of a community or tribe (Cajete, 1994/2001, p. 117). Although writing from his Nuu-chah-nulth belief system, Atleo's approach reveals how an Inuit worldview, its laws, and core principles could be made known to non-Inuit and Inuit alike through such storytelling and analytic commentary. This coupled with the type of historical and contemporary information found in texts such as Human, Predators and Prey (Laugrand \& Oosten (2015), The Arctic Sky (MacDonald, 2000), Sacred Hunt: A Portrait of the Relationship between Seals and Inuit (Pelly, 2001), and Uqalurait: An Oral History of Nunavut (Bennett and Rowley, 2005) would be a good first step along a path toward an accurate understanding of Inuit culture and values. It simulates the way in which Inuit teachers who 
grow up in home and community environments like Eshkibok-Trudeau's daughter, and Atelo himself, learn and teach. They have lived and continue to live lives that are embedded in the history and IQ philosophy that non-Inuit, and many Inuit negatively affected by colonization, struggle to understand.

\section{Collaborative Teaching: Wenzel and the Polar Bear}

Wenzel's (2004) paper is focused on the Nunavut Wildlife Act (Bill 35) that adds seven additional IQ guiding principles to Arnakak's initial list of six. He and most other non-Inuit working in wildlife management in Nunavut consider the first four of these to be "little more than general notions of "Good Stewardship"' (p. 242). However, the remaining three, rather than being person-toperson interactions, are focused on human interactions with wildlife. According to Wenzel these express values (spiritual knowledge) that are specific to Inuit culture.

Wenzel describes three events in which he was involved where the actions and behaviours of the hunters he observed could be linked to Inuit spiritual knowledge, namely: respect for wildlife, only hunting what is necessary, and/or not acting with wrong intent. Although each incident is interesting, I describe only one and ask that you imagine similar settings in which elders and knowledgeable community members collaborate with Inuit and non-Inuit teachers.

In his recounting, Wenzel was with the village leader (hunter) and a dog team looking for late-denning polar bears that were in an area approximately fifty kilometres northwest of Clyde River. They had been travelling for sixteen hours when the hunter detected snow that had rolled to the valley floor from the upper levels of a ravine. As the hunter scanned the ravine, he noticed the opening of a den. According to Wenzel the den was approximately 400 metres ahead of the dog team and 150 metres above their position on the valley floor. Before they could begin their approach, the bear emerged, scented and saw the dogs, Wenzel and the hunter, and sat down in front of the den looking at them. As Wenzel saw the situation, they "were in a position to take a substantial amount of meat" (p. 246): the wind was blowing toward the bear so the dogs were unaware of the bear and, therefore, quiet and non-threatening. He assumed that they would immediately start their approach. Instead, the hunter unpacked a telescope and observed the bear for about three hours. Each time Wenzel expressed concern, the hunter responded that "he had never seen a bear acting as this one did, that he did not understand the bear and that I [Wenzel] should be patient" (p. 246). When the hunter made the decision to begin approaching the bear, he told Wenzel to follow with one dog but to wait a few minutes before starting out. Wenzel did this, and when the hunter was no more than twenty-five metres directly below the bear, he aimed, fired, and killed the bear with that single shot. The approach had taken the hunter approximately one hour, and in that hour the bear had never moved. It simply watched them advance. On the evening of their return to the village with the butchered bear, the hunter shared his story with the community. According to Wenzel, "he repeatedly noted the odd behavior of the bear and how he had become convinced that the successful conclusion of this hunt would turn on discerning how the animal wanted to be approached" (p. 246). Wenzel interpreted what he observed as the hunter being patient to acquire greater knowledge, not acting badly or with wrong intent, respect for wildlife, and being respectful "in a way that... [was] discerned from the actions of the bear" (p. 247).

This is an example of the relationship between animals and human beings, specifically Inuit. Laugrand and Oosten (2015) describe it as "a meaningful [not violent] act in which the hunter and animal are connected as partners" (p. 38). If animals did not show themselves to hunters, people starved. The animal's decision to show itself and be killed depended on the behavior of the hunter and others: "Hunters would only be successful if people behaved respectfully toward the animals and observed correct ritual injunctions" (p. 39). For polar bears this included, among other practices, not making fun or speaking ill of them (p. 186), butchering the carcass on the spot where it was killed, feeding the intestines to the dogs, social sharing of the meat, hanging up pieces of the tongue and other small body parts with small tools attached to them as presents to the bear's soul, and not working for three days subsequent to the kill. The soul of the bear is believed to report its good 
treatment to other bears, which leads to the success of the hunter which can lead to more food "given by animals and accepted by humans" (Stairs \& Wenzel, 1992, p. 1).

I ask that you first think about what a teacher needs to know to share such an incident with Inuit students and to pose the guiding questions that will promote thinking, IQ interpretation of the events, conceptual engagement, and collateral learning. What if a teacher collaborates with an older hunter (elder) who is culturally grounded and wise, and who has access to decades of experience in the world that will enable him to uncover actions as Atleo has done in the Son of Raven story and as Laugrand and Oosten begin to do in their interpretation of hunter-animal partnerships? Now imagine this elder communicating with a hunter out on the land with a group of students and their teacher where the IQ knowledge is embedded in process. How does each one of these scenarios differ from one that portrays a teacher who has not developed her understanding of $I Q$ principles and embedded values and laws beyond that which is addressed in the orientation and two-year mentoring program developed by the Nunavut Ministry of Education? In which teaching-learning situation is the Inuk learner helped to see his place in the world, to walk in two worlds, to develop a strong sense of identity and belonging, to understand his role in improving the common good and what it means to be simultaneously both self-reliant and mutually reliant? As you may recognize, for Inuit these are several of the values that are necessary for personal wellness, successful living, community well-being, and the sustainability of culture.

Who is deciding "what's worth knowing," who is deciding "how it should be taught" and what are the values behind the learning outcomes? These are the three questions upon which discussions were focused during the process of developing the IQ Education Framework for Nunavut Curriculum. It's clear that the answer to the first question is embedded in the learning outcomes provided in the IQ Education Framework. Teachers determine the answer to the second, regardless of what's written in teacher resources, and their knowledge and depth of understanding with respect to Inuit worldview, Inuit culture, Inuit values and beliefs, and Inuktitut will determine the values addressed in teaching. If preservation of Inuit culture and the well-being of Inuit take precedence over all other goals for education, it's obvious that resources like Atleo's Son of Raven story and analysis need to be created for developing understanding of the Inuit worldview, and that teachers need to share their classroom with knowledgeable elders and other well-informed community members so that the central moral laws and guiding principles of $I Q$ are not abandoned as irrelevant, but are acknowledged as indispensable for achieving the balance and harmony that provide a purpose and direction in life and, thus, contribute to personal, family and community well-being.

\section{Conclusion}

The Canadian Arctic is populated by a people who have a unique perception of place, relationships, justice, success, and goodness. Many of the IQ principles and values that have enabled Inuit to survive in one of Earth's harshest environments are ways of living in community that could help all societies to become sustainable and more socially and economically just. Even so, this way of being is showing significant signs of deterioration when one uses the social determinants of health as a measure of a people's and a culture's well-being. The school system has been implicated as having a role in Inuit society being out of balance. Yet, it is education and the infusion of Nunavut school curricula, learning resources, and teaching materials with $I Q$ philosophy that many believe will help to preserve and sustain the Inuit culture and promote well-being. This, however, presupposes that teachers and those creating resources and materials can communicate in Inuktitut and possess considerable knowledge of $I Q$ principles and Inuit cultural values. Given the predominance of nonInuit teachers and their Eurocentric epistemologies, and Inuit teachers whose lives have been negatively impacted by colonialism, this is unlikely to be the situation. In order to secure a culturally relevant education for Nunavut learners, it is necessary to determine the types of resources that will educate these teachers about the Inuit worldview and the value of bi-cultural teaching practices. It is 
suggested that analytic commentary of legends and stories would, as Cajate (1994/2001, p. 117) claimed, "inform... as well as form" the people, including teachers and students, inhabiting Nunavut. In light of the writing of Aikenhead with his colleagues $(1999,2011)$ on bridging cultures and twoway collateral learning, the argument is made for collaborative teaching strategies. An elder or wise community member, who might also be a teacher, would present Inuit knowledge and a teacher well versed in Eurocentirc knowledge would present mandated curricula. This would allow for the type of two-way seeing described by Martin (2012) that enables learners to "walk [with confidence] in both worlds" (Aikenhead \& Elliott, 2012, p. 326). It is believed that both approaches would help to achieve the wellness that Inuit are seeking through $I Q$.

\section{References}

Aikenhead, G., \& Elliott, D. (2010). An emerging decolonizing science education in Canada. Canadian Journal of Science, Mathematics and Technology Education, 10(4), 321-338.

Aikenhead, G., \& Jegede, O. (1999). Cross-cultural science education: A cognitive explanation of a cultural phenomenon. Journal of Research in Science Teaching, 36, 269-287.

Aikenhead, G., \& Michell, H. (2011). Bridging cultures: Indigenous knowledge and scientific ways of knowing nature. Toronto, ON: Pearson Canada, Inc.

Arnakak, J. (2002). Incorporation of Inuit Qaujimajatuqangit, or Inuit traditional knowledge, into the Government of Nunavut. Journal of Aboriginal Economic Development, 3(1), 33-39.

Arnakak, J. (2000). What is Inuit Qaujimajatuqangit? Using Inuit family and kinship relationships to apply Inuit Qaujimajatuqangit. Nunatsiak News, 25 August 2000. Retrieved 27 December 2014 from http://www.nunatsiaqonline.ca/archives/nunavut000831/nvt20825_17.html.

Atleo, E.R. (2004). Tsawalk: A Nuu-chah-Nulth worldview. Vancouver, BC: UBC Press.

Barber, D., (Chief Editor) \& Barber, D. (Photographer). (2009). Two ways of knowing: Merging science and traditional knowledge during the Fourth International Polar Year. Winnipeg, MB: University of Manitoba.

Battiste, M., \& Henderson, J.Y. (2000). Protecting indigenous knowledge and heritage: A global challenge. Saskatoon, SK: Purich Publishing.

Bell, M. (2002). Nunavut literacy development in the context of Inuit Qaujimjatuqanginnut (IQ) Inuit traditional knowledge: A discussion paper. Retrieved 26 December 2014 from

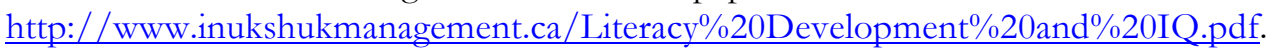

Bennett, J., \& Rowley, S. (2004). Iqalurait: An oral history of Nunavut. Montreal, QC and Kingston, ON: McGill-Queen's University Press.

Berger, P. (2009). Eurocentric roadblocks to school change in Nunavut. Étudies/Inuit/Studies, 33(1-2), 55-76.

Berger, P., \& Epp, J. (2006). Practices against culture that "work" in Nunavut schools: Problematizing two common practices. McGill Journal of Education, 41(1), 9-26.

Cajete, G. (1994/2001). Look to the mountain: An ecology of indigenous education. Skyland, NC: Kivaki Press.

Canadian Broadcasting Corporation (CBC). (2013, November 20). Auditor General: Nunavut won't meet bilingual education goals. CBC News North. Retrieved 27 December 2014 from www.cbc.ca/news/canada/north/auditor-general-nunavut-won-t-meet-bilingual-educationgoals-1.2433233.

Chartrand, R. (2012). Anishinaabe pedagogy. Canadian Journal of Native Education, 35(1), 144-162.

Eshibok-Trudeau, M. (2000). Circular vision: Through native eyes, In R. Neil (Ed.), Voice of the drum: Indigenous education and culture (pp. 13-22). Brandon, MB: Kingfisher Publications.

Government of the Northwest Territories (GNWT). (1996). Inuuqatigiit: The curriculum from the Inuit perspective. Yellowknife, NWT: Department of Education, Culture and Employment.

Government of Nunavut. (2013). Incorporating Inuit societal values: Implementation of Inuit societal values report. Iqaluit, NU: Government of Nunavut. 
Government of Nunavut. (2008). Education Act. Retrieved 26 December 2014 from http://www.nunatsiaqonline.ca/pub/docs/e2008snc15.pdf.

Hampton, E. (1993). Towards a redefinition of American Indian education. Canadian Journal of Native Education, 20(2), 261-309.

Harper, K. (2010). Light and dark, Tiassumani: Around the Arctic. Nunatsiaq News Online. Retrieved 27 December 2014 from http://www.nunatsiaqonline.ca/stories/article/7678 taissumani_january 8

Hogue, M., \& Bartlett, C. (2014). Two-eyed seeing: Creating a new liminal space in education. Education Canada, 54(3), 25-27.

Inuit Tapiriit Kanatami. (2014). Social determinants of Inuit health in Canada. Ottawa, ON: Inuit Tapiriit Kanatami. $\quad$ Retrieved $27 \quad$ December 2914 from https://www.itk.ca/publication/comprehensive-report-social-determinants-inuit-healthnational-inuit-organization.

Inuit Tapiriit Kanatami. (2014). Social determinants of Inuit health in Canada: Education Fact Sheet 3. Retrieved from https://www.itk.ca/publication/comprehensive-report-socialdeterminants-inuit-health-national-inuit-organization.

Jacobs, D. (2013). Teaching truly: A curriculum to indigenize mainstream education. New Your, NY: Peter Lang Publishing, Inc.

Laugrand, F., \& Oosten, J. (2015). Hunters, predators and prey: Inuit perceptions of animals. New York, NY: Berghahn Press.

Laugrand, F., \& Oosten, J. (2009). Transfer of Inuit qaujimajatuqangit in modern Inuit society. Étudies/Inuit/Studies, 33(1-2), 115-152.

Lyons, C. (2015, January 2). Suicides spread through a Brazilian tribe. The New York Times. Retrieved 03 January 2015 from http://www.nytimes.com/2015/01/04/opinion/sunday/suicidesspread-through-a-brazilian-tribe.html?hp\&action $=$ click\&pgtype $=$ Homepage\&module $={ }_{c}-$ column-top-span-region ${ }^{\circledR}$ ion $=\mathrm{c}-$ column-top-span-region $\&$ WT.nav $=\mathrm{c}-$ column-top-spanregion\&_r $\mathrm{r}=0$.

MacDonald, J. (2000). The Arctic sky: Inuit astronomy, star lore, and legend. Toronto, ON: The Royal Ontario Museum and Iqaluit, NU: Nunavut Research Institute.

Martin, D. (2012). Two-eyed seeing: A framework for understanding Indigenous and non-Indigenous approaches to Indigenous health research. Canadian Journal of Nursing Resarch, 44(2), 20-42.

McGregor, H. (2012). Curriculum change in Nunavut: Towards Inuit Qaujimajatuqangit. McGill Journal of Education, 47(3), 285-302.

Mikkonen, J., \& Raphael, D. (2010). Social determinants of health: The Canadian facts. Toronto, ON: York University School of Health Policy and Management.

National Committee on Inuit Education. (2011). First Canadians, Canadians first: National strategy on Inuit Education. Ottawa: ON: Inuit Tapiriit Kanatami (ITK).

Nunavut Department of Education (NDE). (2007). Inuit Qaujimajatuqangit: Education framework for Nunavut curriculum. Iqaluit, NU: Curriculum and School Services Division of the Department of Education.

Nunavut Social Development Council. (2000). On our own terms: The state of Inuit culture and society 2000. Iqaluit, NU: Nunavut Social Development Council.

Nunavut Tunngavik Incorporated. (2013). Annual report on the state of Inuit culture and society - The Nunavut Inuit Health Survey: Understanding its influence and legacy. Iqaluit, NU: Nunavut Tunngavik Incorporated.

Nunavut Tunngavik Incorporated. (2011). 2009/10 Annual report on the state of Inuit culture and society Our primary concern: Inuit language in Nunavut. Iqaluit, NU: Nunavut Tunngavik Incorporated.

Pauktuutit, Inuit Women of Canada. (2006). The Inuit way. Ottawa, ON: Pauktuutit. Retrieved 22 December 2014 from http://www.uqar.ca/files/boreas/inuitway_e.pdf

Pelly, D. (2001). Sacred bunt: A portrait of the relationship between seals and Inuit. Vancouver, BC: Grey Stone Books. 
Raphael, D. (2009). Social determinants of health: Canadian perspectives ( $2^{\text {nd }}$ ed.) Toronto, ON: Canadian Scholars' Press.

Rasmussen, D. (2011). Forty years of struggle and still not right to Inuit education in Nunavut. Interchange, 42(2), 137-155.

Rasmussen, D. (1999). "The queen wishes her red children to learn the cunning of the white man": The myth of educating Inuit out of "primitive childhood" and into economic adulthood. Unpublished master's thesis, Simon Fraser University, Burnaby, B. C.

Rice, B. (2005). Seeing the world with Aboriginal eyes: A four directional perspective on buman and non-buman values, cultures and relationships on Turtle Island. Winnipeg, MB: Aboriginal Issues Press.

Ross, R. (2006). Dancing with a ghost: Exploring Aboriginal reality. Toronto, ON: Penguin Canada.

Simpson, L. (2004). An Inuit way of knowing and the making of Nunavut. Policy Options, August, 8-12.

Stairs, A., \& Wenzel, G. (1992). "I am I and the environment": Inuit hunting, community, and identity. The Journal of Indigenous Studies, 3(1), 1-12.

Statistics Canada. (2009). Table 12: Percentage of Inuit population who reported Inuktitut as mother tongue and as home language, and knowledge of Inuktitut, Canada and regions, 1996 and 2006. Retrieved 25 March 2015 from http://www12.statcan.ca/censusrecensement/2006/as-sa/97-558/table/t12-eng.cfm.

Statistics Canada. (2013). Table 1: Porportion of Aboriginal insntity populations, First nations people, Metis and Inuit for selected Aboriginal language indicators, Canada 2011. Retrieved 25 March 2015 from http://www12.statcan.ca/nhs-enm/2011/as-sa/99-011$\mathrm{x} / 2011003 / \mathrm{tbl} / \mathrm{tbl} 01$-eng.cfm.

Tagalik, S. (2009-2010a). Inuit Qaujimajatuqangit: The role of indigenous knowledge in supporting wellness in Inuit communitees in Nunavut: Inuit Child\& Youth Health. Prince George, BC: National Collaborating Centre for Aboriginal Health. Retrieved 28 December 2014 from http://www.nccah-ccnsa.ca/en/publications.aspx? sortcode $=2.8 .10$ \&publication $=6$.

Tagalik, S. (2009-2010b). Inutsiaqpagutit - That which enables you to bave a good life: Supporting early Inuit life health: Inuit Child \& Youth Health. Prince George, BC: National Collaborating Centre for Aboriginal Health. Retrieved 28 December 2014 from http://www.nccahccnsa.ca/en/publications.aspx? sortcode $=2.8 .10$ \&publication $=5$.

Tester, F., \& Irniq, P. (2008). Inuit Qaujimajatuqangit: Social history, politics and the practice of resistance. Arctic, 61(Supplement), 48-61.

Weber, B. (2014, January 16). Nunavut coroner call inquiry after suicides reach new record. The Globe and Mail. $\quad$ Retrieved $26 \quad$ December 2014 from http://www.theglobeandmail.com/news/national/nunavut-coroner-calls-inquiry-aftersuicides-reach-new-record/article16370558/.

Wenzel, G. (2004). From TEK to IQ: Inuit Qaujimajatuqangit and Inuit cultural ecology. Arctic Anthropology, 41(2), 238-250.

Wihak, C. (2004). Psychologists in Nunavut: A comparison of the principles underlying Inuit Qaujimanituqangit and the Canadian Psychological Code of Ethics. Pimatisinin: A Journal of Aboriginal and Indigenous Community Health, 2(1), 29-40.

Word Health Organization. (2014). Social determinants of health: What are the social determinants of health? Retrieved 28 December 2014 from http://www.who.int/social_determinants/en/.

\section{About the Author}

Barbara McMillan is an associate professor in the Faculty of Education at the University of Manitoba. Her research interests include the impact of curricula that integrate local, cultural, and traditional knowledge on Inuit and First Nations students' confidence and success in school science and the meaning of Inuit Qaujimajatuqangit for Nunavummiut who reside in Manitoba. 